\title{
The Archers at Crecy
}

TN the following pages I have collected \& few passages which will be I found to support MIr. Hereford George's theory of the archer formation at Crecy,' although, indeed, they almost all deal with other battles. Mr. George has not actually been the first to state the theory for one particular battle. Viollet-le-Duc-not quite anticipating Mr. George in that he considered that the English divisions at Crecy were placed one behind another-nevertheless saw that the deadliness of the volleys was due to the archers falling back to the wings as the French cavalry pushed on to reach the dismounted men-at-arms 'in the background.' Pendant que les hommes d'armes à pied soutenaicnt bravement le choc, les archers se jetèrent sur le flanc de l'attaque. ${ }^{2}$ Sir James Ramsay in his 'Lancaster and York,' and Mr. Gardiner in his 'School Atlas,' give plans almost identical with Mr. George's for Agincourt. But the former has not yet worked out the theory for Edward III's battles, and the latter gives a totally different plan for Crecy. Mr. George has alone traced a 'permanent system ' through the whole of the hundred years' war.

I wish to help to strengthen his theory, and to justify an appeal from Crecy to other battles on two grounds. The evolution of the English tactics begins with Falkirk; then comes the defeat of Bannockburn, followed by the revenge at Dupplin Moor and Halidon Hill; the archers further distinguish themselves at Cadsand and Sluys, at the assault of the unwalled town of Coen, and at the passage of the ford of Blanche-Tache. Is it likely that the king himself, and the earls of Warwick, Oxford, and Arundel, and many knights, who were all present at Halidon Hill, ${ }^{3}$ drew up the army at Crecy without remembering how that memorable victory was won, or that they fought on a system devised on the spur of the moment? Secondly, when the French at last learnt that a new weapon and a new formation-new to them, in spite of what they must have heard of battles in distant Scotland, in spito

' Enoligh Historical Reviet, x. 733 seqq. (1895).

2 Dictionnaire du Mobilier Français, vol. vi. Appendix, p. 375.

- Rymer, 15 and $16 \mathrm{July} 1333$. The list of witnesses to the treaties made with Patrick of Dunbar and William Keith concerning the surrender of Berwicts unleas relieved before $20 \mathrm{July}$; bottle fought $19 \mathrm{July}$. 
of their own losses at Caen and Poissy and the Somme-were triumphantly successful against their old-fashioned, clumsy charge of mailed horsemen, they set to work to find a remedy. They fought on foot, leaving only a picked force on horseback to 'rush' the archers, obviously on a plan devised by their Scottish allies; they made their armour stronger and stronger, they cut down their lances to five feet, they used more frequently their heavy axes, and brought pavises into the field. But the English had no need to alter or to add to their dispositions. They simply had to learn how to attack their enemy in the same formation in which they had repulsed him at Crecy. Chandos at Poitiers knows the right moment to quit the defensive and to deliver the crushing counterattack. At Auray he has a scientific general to face, Du Guesclin himself, and his own archery is useless against the heavy armour and pavises; but he wins in the same formation by bringing one dirision to support another, and by utilising to the full his reserve under Hugh Calverley, the ablest English commander next to himself. Navarette is only Auray on a larger scale, the archers being more effective. After a long interval Agincourt is won by Henry's army advancing in the same formation, but without a reserve. The only innovation on the English side is the use of stakes. We are on these grounds completely justified in drawing inferences about one battle from what we know of others; Crecy was fought upon principles learnt by experience in Scotland; after Crecy the same principles had to be perfected, but were not altered. Now Mr. George works out his theory on these lines, but I cannot help thinking that he does not make enough of the earlier battles. He denies that a 'permanent system' was adopted before Crecy. But the chroniclers help us considerably, and the theory can be strengthened by a glance at the years between Bannockburn and the French war.

To speak first on the general necessities of the case from the English point of view. At Falkirk Edward I's heavy cavalry was powerless against Wallace's rings of pikes, so he brought up his archers. But obviously the lances and the bows were separate corps, and the victory was gained because the Scots were stationary; they had not the skill to mancuvre, like the highly trained Swiss pikemen. At Bannockburn Bruce supported his pikes by cavalry, and we have the sudden sweep of the light horse on to the flank of the English front line of archers; then the English knights rode straight at the main army of Scots, and the bulk of the archers left in the rear were useless." Lances and

4 See Mr. George's account of Bannockbarn, Battles of English History, p. 49. The Scots caralry cannot have cut up the whole of the archer force; Baker of Swin. brook (edit. Sir E. M. Thompson, p. 8) distinetly says that the archers were in the rear; so does Abbut Burton of Meaux (Chron. de Melsa, edit. E. A. Bond, Rolle 
bows were still in separate bodies, and were out of touch with each other; moreover the front was too narrow. The English commanders had in the future battles to lay to heart these lessons; they had to fight on a wide enough front, to teach discipline to the impatuous knights, to combine them with the plebeisn archers for mutusl protection, and to utilise the latter fully. At Dupplin Moor and at Halidon Hill we find that these reforms were carried out; knights and men-at-arms fought on foot with their horses held just behind them, and in touch with the archers on the wings, which sloped out towards the enemy en potence.

Not only are men-at-arms and archers in each division, but the archers are the links by which the divisions are connected with each other. On Mr. George's theory the arrangement is an admirable one. There msy be one solid phalanx of dismounted men-atarms in the background, ${ }^{6}$ with each archer wing sloping outwards towards the front, as at Dupplin Moor ; or two such phalanxes, so that the intermediate wings of archers form a hollow wedge, as at Crecy; or three, as at Halidon Hill and Aursy and Agincourt. At all these battles, by the nature of the ground, the two or three divisions must be abresst; but at need they could be arrayed irregularly, as at Poitiers, or en échelon, as presumably at Navarette, and possibly at Auray. The flanks are reasonably secure now, especially if the whole army is posted on a curving slope, because not only is there nearly always a reserve higher up the hill, which, moving on an inner arc, can always get into position long before the enemy can come round on the outside to turn the position, but also because the extreme right or left archer lines can quickly be bent back into the shape of \& wedge, so as to keep him always within range. Agrin, the archers are not to be regarded as animated dummies; they could spresd out in lines parallel to their men-st-arms, gall the enemy as he approached, or by their galling volleys compel him to approach, and then fall back into their wedge-like formation as his charge was pressed home. This is the crisis of each battle which the theory so well suits. The heaviest volleys come from the apex of each wedge, not necessarily acutely pointed, but perhaps somewhat flattened; every passage shows us that, just as in the case of modern artillery, the 'fire' was rapid and concentrated upon certain points of the attacking line, si onniement, as Froissart and others say over and over again. The badly armoured Scots in their unvizored helmets, ${ }^{7}$ or the French horses, which were not

Series, 1867, vol. ii. p. 331). On the other hand there is a constant Scottish tradition that there was this rapid charge on the flant of the foremost archers, besides Barbour's well-known lines.

S Chronicle of Lanercost (edit. J. Stevenson, p. 225) : 'Istum processum audivi a quodam fidedigno, qui fuit proesens et vidit.'

- 'Ou fons de leur bataille,' Froissart's celebrated phrase for Crecy.

- Chronicle of Lanercost, pp. 268, 273. Dupplin Moor: 'Its excrecsperunt ef 
completely ' covered,' were blinded and maddened. Like sheep they poured along and streamed into the space of least resistance, i.e. where the arrows fell least densely, between the sloping archer lines; they blundered along, with their heads down, and now the volleys were aimed into their flanks; they swerved inwards, but atill they managed to reach the steady lines of the English men-atarms; by mere weight they even forced the latter somewhat back. But orderly lines must prevail over disorderly rushing mobs. The English men-at-arms held their ground, the archers still poured in their shafts from the wings, and the charge expended itself. The language used in the accounts of Dupplin Moor and Agincourt might refer to one and the same battle; and $\mathrm{Mr}$. George has insisted on this being the correct account of Crecy. The English men-at-arms come into action without disordering their own archers. More than this, they face the enemy while the archers still keep up their murderous ' fire.'

Dopplis Moon.-The expedition of Edward Baliol to win the throne of Scotland was really an English one. His supporters, such as Gilbert of Umfraville, earl of Angus, and David Hastings of Strathbogie, earl of Athole, Henri de Beaumont, Wake, and others, were the 'disinherited' nobles of the anti-Bruce faction, of Norman or French descent, who claimed estates in Scotland by marriages or by grants. They were in reality as English as the Percies or Nevilles. It was an English ${ }^{8}$ expedition, the start was from the Humber, and the Lanercost chronicler always calls them Anglici. Of our chief authority, the anonymous canon of Bridlington," the bishop of Oxford says that we are "arguing in the dark' as to this exact date of writing. The present form of chronicle points to a date about 1877 , but the 'original draft' by internal evidence seems to end at 1939 and to belong to one writer. The account is so graphic, and there is so much detail, that we are almost justified in thinking that the canon got his information at first hand from some soldier returning to his Yorkshire home. The inmates of the northern religious houses were usually well posted in the events of the Scottish wars, for the raids from over the border materially affected them, and at least the traditions of battles had more meaning for them than, let as say, for the chroniclers of St. Albans.

Our canon says (p. 104) that when Baliol's little army first landed in Fife, and had a brush with some Scots, the knights had

pulneraverunt in facie.' Halidon: 'Vulnerati in facie et excrecati in hoc bello, sicut in priori apud Gledenmore, quod se ipsos adjuvare non poterant, et ideo oito taciem sagittarum ictubus avertere et cadere inceperunt.'

- The celebrated Walter Manny accompanied this expedition (Robert of Avesbury, ed. Sir E. M. Thompson, p. 296).

- Gesta Edwardi Tertii Auctore Bridlingtoniensi, printed in the Chronicles of the Beigns of Edward I and Edward II, vol. ii., ed. Stubbs, Rolls Series, 1883. 
to fight on foot, equis etiam nondum de navibus eductis. This is the earliest hint of the new English policy of dismounting, and suggests that it was originally accidental, and was continued becsuse found to be so effective. $\mathrm{He}$ does not sctuslly say thes they fought slso at Dupplin Moor on foot, but we gether it from his account. He gives as the important battle on p. 106. The English army wos composed of 500 equites et armati, mille pedites et sagittarii.

. . D Dispositis itaque turmis et sagittariis suis, ut collatersles cuneos hostium invaderent, ipsi armati magnum exercitum expugnabant. Et facto congressu Scotorum impetum primo non ferentes, aliquantulum retrocedere compelluntur, et de superius animati resistunt clypeos ictibus pretendendo; hostium vero minores turmso per sagittarios plurimum lacerati, adhserere magno exercitui compelluntur, et in brevi conglobsti alius ab alio premebstur; ita a suis suffocati, et megis quem gladiorum ictibus verberati, acervum valde mirabile componebant. Sicque condensati, sc si fuissent funibus colligati, misersbiliter expirabsnt. . . . Mrsss siquidem vel acervus proedictus altitudinem quindecim pedum habebat.

The Lanercost chronicler (p. 2068) has been already quoted as drawing our attention to the blinding effect of the archerg; the Scots, he says, were wounded in the face and utterly routed;

in primo tamen congressu, quando Anglici et Scotti fixis in alterutrum lanceis confligebant, Scotti repellebant Anglicos quasi per viginti pedes vel triginta.

Mr. J. H. Burton talks of this battle as 'one of the mysteries of war,' and of 'the enormous slaughter which beyond all doubt befell the army,' the very largest figures of the victorious army being barely over $3,000 .^{10}$ There is no mystery here, any more than there is at Agincourt, if we reasonably adopt MIr. George's theory of the formation-the archers now for the first time acting on the flanks of the Scots and rolling them into one helpless mass; it was a mystery only to those who, with the memory of Bannockburn behind them, thought themselves invincible.

HaLidon HiLl.-The tactics, according to the canon of Brid. lington, were the same. But, as Edward of England had now come to the assiatance of Edward Baliol, the army was much larger. It was formed into three divisions, each with wings, instead of the one division with wings, as at Dupplin Mloor. On p. 114 he saysRex Angliae ... reliquam vero exercitum in tres cuneos tunc divisit. Quorum primum marscallo" fratrique suo Johanni de Eltham comiti Cornubiae . . . commendavit. Comes de Ascecle [Athole] David huic turmae alam a dextris versus mare, et comes de Angos Gilbertus de Unfravills alium a laeva similiter faciebat. Secundam vero aciem ipse

10 History of Scotland, ii. 315. Robert of Aresbary, as above, p. 296, confirms the Bridlingtonian, 1,500 men.

"Thomas of Brotherton, earl of Norfolk, the king'o uncle. Bymer'o Foedera 15 and $16 \mathrm{July,}$ 1333, show that he was present. 
rex Anglizo hinc inde, ut superius, alis compositis; tertiam quoque turmam regi Scotiae Balliolensi, alis ut superius dispositis, ut instrueret, assignavit. Sagittarii alis singulis deputantur.

The battle need not be described. All the chroniclers give the glory to the archers, but it is clear that the men-at-arms came into action, as well as the picked reserve of 200 horse. The Lanercost chronicler ( $p .273$ ) has an expressive phrase; the leading Scots, blinded as they were by the arrows, swerved and wheeled round to attack Baliol's left division (diverterunt se Scoti quod primo obriaverunt). Baker of Swinbrook ${ }^{12}$ has it that this was the first battle where the English men-at-arms fought on foot, in conscious imitation of the Scots.

The Campajan of 1346.-One interesting detail of the attack upon the unwalled town of Caen is to be found in the official bulletin sent to the archbishop by Lord Burghersh.13 It shows that the policy of supporting archers by men-at-arms was the secret of the English tactics.

Et quant nous estoiomus venuz tot a la ville, si pres com nous poyemus, noz archers alerunt tot dreit a pount et les asailerunt par trere. Et en le meyn temps vindrunt a eux ascuns gentz darmez et lour donerunt fort assut, si qe pur doute de blessure de noz gentz, par cause qe home quida qe nuls gens darmez de noz i fusount, forke archers moun Seignur de Warewyke, mareschal, il fut maunde de part le roi pur eux retrere.

It is not for me to discuss the meaning of herce as Froissart used it, but a corroboration of the 'hollow wedge' theory is forthcoming. The baron Kervyn de Lettenhove quotes in his notes to Froissart a certain chronicle of Valenciennes, ${ }^{14}$ which may or may not be the work of a man who understood tactics, but the following words contain a strong undesigned coincidence. The king ne fist que deux batailles d'archiers à deux costés en la manière d'un escut; et au milieu d'eulx se tenoit le prince de Galles. Our chronicler thought that the Black Prince, Warwick, Northampton, Arundel, Suffolk, and all their men formed only one division with archer wings, in a shield-shaped, i.e. wedge-like, formation. His mistake is slight in comparison; his support of Baker's language and of those who translate herce by 'wedge' is considerable. Compare Wavrin's similar mistake for Agincourt.

NevirLE's Cross.-Abbot Burton of Meaux ${ }^{15}$ wrote at the end of the fourteenth century. Mr. E. A. Bond, the editor, ${ }^{16}$ says that

12 Ed. Sir E. M. Thompson, p. 51.

13 Adam of Murimuth, ed. Sir E. M. Thompson, pp. 202, 203.

it Froissart, v. p. 474, notes.

is Not quoted previously for Dupplin Moor, because his words there are almost identical with those of the canon of Bridlington. For Halidon Hill bis account is meagre (ii. 364, 370).

10 Preface to Chron. de arelsa, vol. 1. pp. zliv, zlix, yol. ii. pp. xxxip, xxav the battle, iii. 61. 
he wrote from earlier sources, and his language closely resembles and often is identical with that of a Cistercian manuscript of the same date; the account which each follows has the air of coming from some northern monastery of Cistercians. He makes the figures both of the soldiers engaged and of the slain and prisoners fairly small-not indeed small enough according to the pay list in Rymer, ${ }^{17}$ but small enough to satisfy us that he does not let his imagination run riot. He says of the battle-

Uterque autem exercitus gentes suas in tres acies dividebat sagittariis a latere constitutis.

The Scots and English faced each other at a distance of a quarter of a mile, and each army was resolute not to move.

Sed quingenti sagittarii Anglici praecurrentes Scottos missilibus multipliciter confossos locum prius occupatum deserere et ad conflictum pergere provocsbsnt. Et statim factum est ut omnes acies pedestres pariter conflixerunt. Et Anglici primo aliqualiter retrocedere compelluntur, sed vires resumentes Scottis ictus debitos rependerunt.

Auray. - Sir John Chandos in this battle formed three divisions and a reserve, each of 500 men-at-arms and 300 archers. It is noteworthy that in battles where the archery was ineffective the proportion of bows to lances is small; 10 to 4 is an ordinary proportion in the great victories. On this occasion the archers made no impression on the densely packed French and Bretons.

Bien est verités que li arcier traiirent de commencement; mès leurs très ne grev noient as François, car il estoient trop bien armet et fort, et ossi bien paveschiet contre le tret. Si jettèrent cil arcier leurs ars jus, qui estoient fort compagnon, able et legier, et se bouterent entre les gens d'armes de leur costé, et puis s'en vinrent dè ces Franchois qui portoient ces haces. Si se aherdirent d̀ iaulx de grant volenté, et tollirent de com. mencement as pluiseurs leurs haces, de quoi il se combatirent depuis bien et foiticement.18

These active and light fellows were far from being useless when their arrows were ineffoctive. They hurled themselves on the enemy without getting in the way of their own men-at-arms, and by their side. The theory of the archer wings of all three divisions forming intermediate wedges suits this language. Froissart, whose geography is, according to $\mathbb{M}$. Luce, very much at fault, nevertheless received his facts of the battle from the herald who brought the news to King Edward, and from knights on either

17 Viz. 900 men-at-arms and 9,000 archers. In Rymer, 20 March 1947, payment is ordered for 480 men-st-s,rms and 2,880 archers; the contingents of all the prominent commanders are given, but not those of the churchmen. On other occasions his figures ore often much too bigh.

10 Froissart, Societé de l'Histoire de France, ed. Luce, vi. 163, chap. 537.

POL. XIJ. - NO. XLVII. 
side. ${ }^{19}$ He describes this battle much more clearly than is usual with him, as if he mode his first draft of it immediately after the event.

Navaretre or Najara.-Froissart's account is almost as indistinct for this battle as for Crecy; he has abiandoned the clear style which he momentarily adopted for Auray. But an anonymous writer, the chronicler of the 'Quatre Premiers Valois,' whose accuracy is strongly praised by his editor, M. Luce, gives us a hint of the use made of the erchers. Where the right division of English, under John of Gaunt and Chandos, faced Du Guesclin and the French allies of Spain,

trop greve les diz Françoiz une bataille d'archiers d'Angleterre, bien trois mille et plus, qui traioient de travers leur bataille sur eulx tant asprement que a pou qu'ilz ne veoient goute, et alors prindrent les Françoiz \& branler. ${ }^{20}$

Evidently a flank attack broke the French, but it is not clear whether these 3,000 archers belonged to the wings of Chandos's division, or were the same as the 3,000 sent by the prince from his main body, whom the chronicler mentions on the next page.

Aarncourt. - It is needless to quote again in full the words of the chaplain, who says that 'wedges' of archers were 'mixed' between the three divisions of men-at-arms. Cuneus is in itself a vague term, though the choice of intermiscuisset points to its literal meaning; so herce and escut, the words employed in the case of Crecy, may not mean 'wedge;' but the use of three words by three independent writers, two of them writing of the same battle, which all can mean 'wedge,' is a strong argument. But another pessage from the chaplain supports my application of Mr. George's theory. He says-

Sed Gallorum nobilitas quae plena fronte prius accesserat, ut de prope coniunctionem venerst, vel timore telorum, quorum adversitas eos reptabst per laters et umbracula cassidum, vel ut citius penetrarent nostram fortitudinem ad vexilla, diviserunt se in tres turmas, invadentes bellum nostrum in tribus locis ubi erant vexills; et in prims mixtione lancearum tam feroci impetu grassati sunt nostros, quod eos fere ad longitudinem lanceae retrocedere compulerunt. . . . Et tuno bellum infervebat asperrimum, et sagittarii nostri transfixerunt et immiserunt telorum aculeos per laters. . . . Sicque in tribus locis ubi erat fortitado ef acies vexillorum nostroram, tanta crevit congeries occisorum et interiscentium oppressorum, quod nostrates ascenderunt ipsss congeries, quse creverant ultro altisudinem longitudinis hominis."1

The fact that the charging French parted into three divisions in. dicates that the hotly concentrated volleys from the points of the two intermediste wedges, 28 well as from the outside wings, forced fbem

10 Ibid. p. 173.

20 Published by the Sociéte de l'Histoire de France, ed. Luce, p. 179.

"Gesta Henrici Businti, ed. Williamo, English Historical Society, pp. 53, 5j. 
to huddle themselves blindly into the three spaces of least resistance, and so on to the men-at-arms. Then the arrows came in on their flanks, and the dead were afterwards found in three great heaps.

But the chaplain was not the only eye-witness. Two Burgundians saw the fight, St. Remy on the English side, and Wavrin, himself a soldier, on the French side. Their accounts are almost identical, but not entirely so; they shared their information with each other. Wavrin wrote much later, ${ }^{22}$ as if he set himself to record what he had previously told St. Remy, and partly to correct him. A soldier's reminiscences may in after life become confused, but are valuable as coming from a soldier. He says-

Le roy . . . ne fist de tous ses gens que ung tropel le plus estroit et amasse quil peult, ses gens darmes ou millieu et toutes ses banieres assez prez lune de lautre; a deux costez des hommes darmes estoient les archiers.

(We cannot believe that Henry really only formed one division: Warrin, as St. Remy before him, may have confused this battle with Verneuil. But at least he definitely puts the archers on the wings.) After the useless conference between Henry and the French lords

le roy avoit ordonne ung chevallier nomme messire Thomas Harpingbuem pour mettre a point ses archiers au front devant en deux hesles. ... Et quant les Anglois veyrent que point ne les aprochoient les Francois, ils marcherent devers eulz tout bellement. . . . Lors les archiers dAngleterre quy, comme jay dit, estoient sur hesle, se veyrent estre prez assez, ils commencerent a tyrer. . . . Mais les Francois commencerent a encliner leurs chiefz, especialement ceulz quy navoient nulz pavaiz, pour limpetuosite du trait Anglois, qui cheoit si onniement que nulz nosoit soy descouvrir ne regarder en hoult, et ainsi allerent on peu avant si les firent quelque petit reculler, mais anchois quilz peuissent aborder ensamble y eut moult de Francois empeschies et navrez du trait, et quant ilz furent venus jusques auz Anglois ilz estoient, comme dit est, si prez serrez lun de lautre quilz ne povaient lever leurs brachz pour ferir sur leurs annemis, sinon aulcuns quy estoint au front devant. ${ }^{23}$

Beyond the important discrepancy as regards the one division where the chaplain says three, this description is powerfully corroborative of the other. But what was 'old Sir Thomas Erpingham' ordered to do? The English had already advanced and taken up ground in their usual battle order; therefore Henry's new orders cannot but have been to throw forward some archers to gall the French and to make them attack. ${ }^{2+}$ The French, in spite of

22 Jehan de Wavrin, chevalier, seigneur du Forestel, ss he styles himself, wrote a Recueil des Croniques d'Engleterre; Rolls Series, ed. W. Hardy, 1864 ; introd., esp. p. xlii. He was about twenty jears old at Agincourt, and his fatber and brother were there slain.

3 Ed. W. Hardy, Rolls Seriez, 1868, pp. 203, 211-213.

2* See Colonel Llojd, Exolisu Histonical Review, x. 539, July 1895. 
their heavy armour and vizored bacinets, cannot endure the buffet. ing, any more than the badly equipped Scots in former days. Then we get the usual charge, archers falling back to their wedges, French pushing on blindly with their heads down, just like the Scots at Dupplin Moor and Neville's Cross, unconsciously pressing inwards, even by sheer weight driving the English men-at-arms a bit backwards, then huddled into a powerless mass and destroyed.

The lines from Elmham's metrical account, based clearly on the chaplain, leave us in no doubt as to the impression left on his mind of the English trectics. ${ }^{25}$

Francorum turma prorupit ad arcitenentes;

Turbo sagittarum vertere terga dedit.

Horum nobilitas in fronte, tribus data turmis, Ad vexilla tribus intulit arma locis :

Quorum sunt latera nostris penetrata sagittis, Fronsque per armatos hostica trita fuit.

VERNEUIL. - Wavrin writes-

Les Anglois, en gectant ung hault cry, commencerent de marchier et aller avant en bonne ordonnance, les archiers sur les deux hesles. ${ }^{26}$

Monstrelet puts this rather more strongly-

et furent mis les archers au front devant, ayant chascun ung penchon devant eulx aguisé et fiché en terre. Et estoient les plus grans foucz (forces or foules?) desdiz archers vers les deux bous de la bataille en manière de beles. ${ }^{27}$

If most of the archers were on the wings, the remainder must have been the skirmishers, who could have only had the wings to retreat to when the shock of battle came. Also the stakes would only have been planted when the enemy was close. The duke of Bedford by this time apparently had made the innovation of fighting in one large division in place of three, very possibly because the stakes encumbered the archers. They lost in mobility what they gained in defence. But, as at Agincourt, the English and their allies were the attackers. The battle, as Wavrin and all the others show, was won by the archers of the reserve, falling fresh on the French flanks after the main bodies had fought hard for some three-quarters of an hour.

A comparison of these passages shows that for a period of a hundred years the English tactics remained the same, and what is true of one battle is more or less true of another.

J. E. MoRris.

25 Rolls Series, 1858, ed. C. A. Cole, preface, p. sliii, and pp. 121, 122.

s9 Ed. W. Hardy, 1879, p. 110.

37. Ed. Douët-D'Areq, for the Societé de l'Histoire de France, iv. 193. 